\title{
Rifkin tries to block human gene transfer experiment
}

\section{Bethesda}

THE first experiment to insert foreign genes into humans, which received approval to proceed only two weeks ago, may be blocked by Jeremy Rifkin, an active opponent of genetic engineering.

On 30 January, Rifkin's Foundation on Economic Trends filed a suit in a US federal district court to stop W. French Anderson of the National Heart Lung and Blood Institute and R. Michael Blaese and Steven A. Rosenberg of the National Cancer Institute from carrying out the experiment. The plan is that tumour-infiltrating lymphocyte (TIL) cells marked with a gene for antibiotic resistance will be injected into ten cancer patients from whom the cells were isolated.

Rifkin has filed his suit because he says the approval process of the National Institutes of Health (NIH) did not fully review the experiment or allow for public debate in the final stage. But NIH officials point out that there has been ample opportunity for open discussion and the experimental protocol has undergone a complex and lengthy review process.

The road to approval for the gene transfer experiment has not been smooth. Anderson and his colleagues first proposed their experiment last June, and it was referred first to various institutional review committees and then to the NIH Recombinant DNA Advisory Committee (RAC) for approval. A RAC subcommittee on human gene therapy first concluded that more data were needed, but at the end of September, Anderson told the subcommittee that he did not have the data it was seeking, whereupon the committee deferred approval of the protocol.

But on 3 October, Anderson presented much of the same data to a full meeting of the RAC, which approved his experiment. NIH director James Wyngaarden ordered that the subcommittee be given a second chance to review the proposal in the light of the new data, and the application was afterwards resubmitted to the full RAC, which approved it by mail ballot

Rifkin objects to the mail ballot. Andrew Kimbrell, policy director and attorney for Rifkin's foundation, says that after the 3 October meeting, significant changes were made to the experimental protocol which under federal law should have been debated in an open RAC meeting, adding that the RAC review process in this case has been "confused, backwards and illegal". Speaking at this week's RAC meeting, Wyngaarden countered that there were no substantive changes to the protocol approved at October's open RAC meeting, so a further public meeting was unnecessary. The gene therapy com- mittee's final deliberations, held on 9 December, were public.

But Wyngaarden does agree that the Anderson case has pointed to a problem with RAC procedures. He announced last Monday that he would seek an amendment to the RAC charter requiring that protocols referred to a RAC subcommittee to be approved by that subcommittee before being put to the full RAC.

Anderson says he thinks Rifkin's lawsuit is "a good thing" because it will bring the issue out in the open for public discussion. But Rosenberg points out that an American dies from cancer every minute, and "any delay for any reason would be very unfortunate."

Rifkin also used the forum of the RAC meeting to propose an amendment to NIH guidelines that would establish a Human Eugenics Advisory Committee to provide advice on the "ethical, philosophical, social, economic and eugenic implications and impacts of human genetic therapy".

But RAC chairman Gerard McGarrity pointed out that the RAC does not have the administrative authority to create such a committee. Such amendments can only be made by the Secretarty of the Department of Health and Human Services who approves RAC's charter. Nevertheless, the RAC spent nearly two hours debating the merits of the proposal, and although there was general support for the idea, most felt existing review bodies could cope with the issues that a eugenics committee would address. David Swinbanks

\section{Errors in US census rouse political protests}

\section{San Francisco}

Time is running out to resolve the political and legal challenges to the way the 1990 US census will be conducted. Yet practical issues such as how to count the minority population of large urban areas and whether to count illegal aliens will have a profound effect on the social fabric of the United States in the next decade.

The decennial census is used not only for allocation of congressional representatives among the 50 states, but also for the distribution of federal funds to states and cities for services such as hospitals, schools, highways and housing. But the census usually misses 10 per cent or more of the minority population in some urban areas, and the cities most hurt by the undercount have accused the Bureau of the Census of ignoring a proven statistical means of correcting the numbers.

Census bureau decisions are subject to strong political pressures, as a small change in population can mean the gain or loss of a congressional seat. Since 1970 , the census has been taken largely by mailed questionnaires; enumerators are sent in person only to households that do not respond. The method runs into difficulties in poor urban neighbourhoods.

After the 1980 census, the census bureau faced 37 lawsuits by areas contending that their minority population had been undercounted, all of which were unsuccessful. Nevertheless, the bureau developed a method called the Post Enumeration Survey (PES), using an indepth survey of 300,000 households drawn from representative city blocks, to adjust its first counts. A test of PES in Los Angeles demonstrated a 9 per cent undercount in black neighbourhoods.

Barbara Bailar, chief of the team that devised the method, acknowledges that PES will still miss people who actively avoid being counted, but says it will nevertheless bring the numbers closer to the truth. Despite endorsements from three scientific committees, the census bureau has decided not to use PES to adjust the 1990 census. The bureau claims its existing methods are sufficiently accurate, and that PES would be too expensive.

Bailar resigned in protest at the decision, complaining that the census uses other, less-sound adjustment methods costing more than the $\$ 31$ million required for PES. Some claim that the decision is politically motivated by Republican fears of losing congressional seats, as the undercounted populations typically vote Democratic.

Meanwhile, a coalition of cities and minority advocacy groups has launched a lawsuit to compel the bureau to shift to PES. A bill with the same objective introduced in Congress was killed last September by the addition of an amendment requiring the exclusion of illegal aliens from the census. The census does not at present aim to determine citizenship, and the census bureau is being sued by a coalition of congressmen who oppose counting illegal aliens for apportionment of congressional seats.

The census bureau defends the inclusion of illegal aliens on the grounds that the constitution requires counting all residents. In any case, says Jeffrey Passel of the census bureau, excluding illegal immigrants would be difficult because it would require the determination of citizenship, requiring all non-citizens to be matched against Immigration and Naturalization Service records, known to be in disarray.

Marcia Barinaga 